\title{
Pengembangan Strategi Pengelolaan Sanggar Srengenge Mas Bantul
}

\author{
Janu Riyanto \\ Program Pascasarjana Institut Seni Indonesia Yogyakarta \\ janukaer@gmail.com
}

\begin{abstract}
Abstrak
Penelitian Pengembangan Strategi Pengelolaan Sanggar Srengenge Mas, Bantul, DIY bertujuan mengidentifikasi strategi yang digunakan selama ini dalam mencapai tujuan yang telah ditetapkan. Di samping untuk menganalisis faktor internal dan eksternal serta memformulasikan pengembangan strategi yang digunakan Sanggar Srengenge Mas. Metode penelitian yang digunakan meliputi empat tahap. Tahap pertama menentukan lingkup penelitian yang terdiri dari objek penelitian dan subjek penelitian. Langkah kedua, melakukan teknik pengumpulan data. Langkah ketiga menentukan variabel yang mencakup faktor internal (kekuatan dan kelemahan) dan faktor eksternal (peluang dan ancaman). Langkah keempat atau terakhir, melakukan analisis data dengan menggunakan metode kualitatif dengan menggunakan analisis SWOT. Hasil penelitian berdasarkan matrik IE, Sanggar Srengenge Mas berada di posisi V, yakni Hold and Maintain (pertahankan dan pelihara). Strategi umum yang dipakai adalah penetrasi pasar dan pengembangan produk. Hasil penelitian kedua, berdasarkan kuadran analisis SWOT Sanggar Srengenge Mas berada di kuadran I sehingga diperlukan pemilihan strategi berupa penggunaan setiap kekuatan untuk menghadapi setiap ancaman dengan mendukung strategi ofensif guna menciptakan peluang. Hasil penelitian ketiga, berdasarkan hasil Kuadran Analisis SWOT Sanggar Srengenge Mas menunjukkan posisinya berada pada kuadran I yaitu Ekspansion mendukung strategi ofensif.
\end{abstract}

Kata kunci: pengembangan strategi, sanggar seni, analisis SWOT, formulasi strategi

\begin{abstract}
Research on the Management Strategy Development of the Srengenge Mas Studio, Bantul, DIY aims to identify the strategies that have been used so far in achieving the stated objectives. Besides analyzing internal and external factors and formulating the development of strategies used by Srengenge Mas Studio. The research method used includes four steps. The first step determines the scope of the study which consists of the object of research and research subjects. The second step is to carry out data collection techniques. The third step determines variables that include internal factors (strengths and weaknesses) and external factors (opportunities and threats). The fourth or final step is to analyze the data using qualitative methods using SWOT analysis. The results of the study are based on the IE matrix, Sanggar Srengenge Mas is in position V, namely Hold and Maintain (keep up and maintain). The general strategies used are market penetration and product development. The results of the second study, based on the SWOT analysis quadrant Srengenge Mas Studio, were in quadrant I, so a strategy was needed in the form of using each force to deal with each threat by supporting an offensive strategy to create opportunities. The results of the third study, based on the results of the Srengenge Mas SWOT Analysis Quadrant, show that their position is in quadrant I, namely expansion, supporting offensive strategies.
\end{abstract}

Keywords: strategy development, art studio, SWOT analysis, strategy formulation 


\section{PENDAHULUAN}

Sanggar Srengenge Mas berdiri sejak 27 September 2010, berawal dari keprihatinan dari pendirinya, yakni Akhir Lusono terhadap mulai terpinggirkannya budaya seni tradisi, di antaranya seni gurit, tari tradisional, dan penulisan cerita pendek berbahasa Jawa serta pementasan drama berbahasa Jawa. Ini ditandai dengan semakin sedikitnya jumlah peminat yang menggeluti seni tradisi jenis ini.

Akhir Lusono bersama sejumlah penggiat seni tradisi lainnya membuat Sanggar Srengenge Mas sebagai upaya untuk pelestarian dan pengembangan seni tradisi, terutama seni gurit, tari tradisional, dan penulisan cerita pendek berbahasa Jawa serta pementasan drama berbahasa Jawa yang berlokasi di Cebongan RT 11, Dukuh 4, Ngestiharjo, Kasihan, Bantul.

Pada awalnya, sanggar itu hanya mewadahi warga sekitar yang punya minat dan hobi untuk belajar dan menampilkan beberapa bentuk seni tradisi. Namun, seiring dengan aktivitas sanggar yang semakin tinggi, maka anggotanya bukan hanya warga sekitar, namun juga dari berbagai wilayah di DIY.

Sanggar Srengenge Mas juga sudah tercatat di Dinas Kebudayaan DIY dan sudah sering melakukan pementasan, termasuk mengisi acara di radio dan televisi lokal DIY. Lewat pementasan-pementasan inilah Sanggar Srengenge Mas saat ini sudah cukup dikenal di masyarakat, khususnya para penggiat seni tradisi.

Dalam menjalankan visi dan misinya, Sanggar Srengenge Mas dihadapkan pada banyak kendala dan tantangan, terutama kian berkembangnya industri hiburan di tanah air yang berkiblat pada budaya barat hingga perlahan tapi pasti menggusur seni tradisi dari masyarakat, sehingga diperlukan strategi yang tepat untuk menghadapi segala kendala dan tantangan ini dengan memanfaatkan potensi yang dimiliki sanggar maupun potensi yang bersifat eksternal.

\section{METODE}

\section{Objek Penelitian}

Objek penelitian adalah Sanggar Srengenge Mas yang berlokasi di Cebongan RT 11, Dukuh 4, Ngestiharjo, Kasihan, Bantul.

2. Subjek Penelitian

Subjek penelitian adalah pengelola inti dari Sanggar Srengenge Mas, terdiri dari tiga orang, yakni Akhir Lusono sebagai Ketua, Marfuana sebagai Sekretaris, dan Sugiyanto sebagai Bendahara.

\section{Teknik Pengumpulan Data}

Teknik pengumpulan data dengan wawancara terhadap pengelola inti Sanggar Srengenge Mas dan kuesioner yang merupakan instrumen penelitian yang digunakan melalui daftar pertanyaan yang diisi responden (key person) yang digunakan bahan untuk pengisian bobot dan rating. Untuk melengkapi data juga digunakan dokumentasi, yakni pengumpulan dan pengolahan serta penyimpanan informasi untuk mendukung penelitian ini. 


\section{Variabel Penelitian}

Penelitian ini dilakukan melalui dua faktor, yaitu faktor internal (kekuatan dan kelemahan) serta faktor eksternal (peluang dan ancaman).

\section{Analisis SWOT}

SWOT merupakan singkatan dari: Strengths (Kekuatan), Weaknesses (Kelemahan), Opportunities (Peluang/Kesempatan), Threats (Ancaman).

Dalam sebuah organisasi, manajer/ketua harus dapat menemukan kesesuaian strategis antara keempat hal tersebut. Analisis ini nantinya harus dapat mengidentifikasi kompetensi yang dimiliki sebuah organisasi (sanggar) yang dapat mencerminkan keunggulan kompetitif yang dimiliki perusahaan.

a. Strengths (Kekuatan)

\begin{tabular}{|c|l|}
\hline No & \multicolumn{1}{|c|}{ Kekuatan } \\
\hline A & Punya bidang garapan yang belum banyak disentuh oleh sanggar-sangar lainnya. \\
\hline B & $\begin{array}{l}\text { Punya anggota yang cukup militan dan fanatik terhadap program yang dijalankan } \\
\text { sanggar. }\end{array}$ \\
\hline C & Punya jaringan media yang cukup luas. \\
\hline D & Punya jadwal tampil yang tetap di sejumlah stasiun radio. \\
\hline
\end{tabular}

b. Weaknesses (Kelemahan)

\begin{tabular}{|c|l|}
\hline No & \multicolumn{1}{|c|}{ Kelemahan } \\
\hline E & Punya peminat yang relatif terbatas. \\
\hline F & Jumlah anggota yang tidak begitu banyak. \\
\hline G & Jangkauan terbatas. \\
\hline H & $\begin{array}{l}\text { Belum cukup menasional, karena programnya hanya menjangkau wilayah DIY } \\
\text { dan sebagian Jawa Tengah. }\end{array}$ \\
\hline
\end{tabular}

c. Opportunities (Peluang/Kesempatan)

\begin{tabular}{|c|l|}
\hline No & \multicolumn{1}{|c|}{ Peluang } \\
\hline A & $\begin{array}{l}\text { Kesempatan untuk berkembang masih terbuka dengan bersinergi dengan pihak- } \\
\text { pihak terkait. }\end{array}$ \\
\hline B & Punya kesempatan untuk mendapatkan subsidi dana dari pemerintah. \\
\hline C & Masih punya peluang untuk memperluas wilayah cakupan. \\
\hline
\end{tabular}

d. Threats (Ancaman)

\begin{tabular}{|c|l|}
\hline No & \multicolumn{1}{|c|}{ Ancaman } \\
\hline D & $\begin{array}{l}\text { Berkembangnya teknologi hiburan yang menawarkan banyak alternatif } \\
\text { hiburan. }\end{array}$ \\
\hline E & $\begin{array}{l}\text { Banyaknya sanggar seni yang menawarkan program yang lebih populer dan } \\
\text { kekinian. }\end{array}$ \\
\hline
\end{tabular}


Tahapan dalam SWOT

1. Pemberian Bobot

Bobot menunjukkan tingkat kepentingan relatif suatu faktor terhadap keberhasilan usaha dalam suatu perusahaan atau organisasi. Bobot tiap faktor diperoleh dengan menentukan nilai tiap faktor terhadap total nilai faktor. Bobot yang diberikan berada pada kisaran 0,000 (tidak penting) hingga 1,000 (paling penting). Faktor-faktor yang memiliki pengaruh besar pada organisasi diberikan bobot yang tinggi. Jumlah seluruh bobot yang diberikan harus sama dengan 1,000. Bobot setiap variabel diperoleh dengan membagi total nilai setiap variabel terhadap total nilai keseluruhan variabel. Rumusnya sebagai berikut.

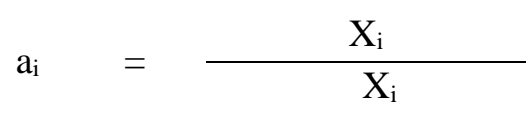

Keterangan:

$$
\begin{aligned}
\mathrm{a}_{\mathrm{i}} & =\text { Bobot variabel } \mathrm{i} \\
\mathrm{X}_{\mathrm{i}} & =\text { Total variabel } \mathrm{i} \\
\mathrm{i} & =\text { ke A,B,C,... }
\end{aligned}
$$

Penentuan bobot pada setiap variabel digunakan skala 1, 2, 3. Penilaian untuk setiap skala dapat dijelaskan sebagai berikut:

$1=$ jika indikator horizontal kurang penting daripada indikator vertikal.

$2=$ jika indikator horizontal sama penting dengan indikator vertikal.

$3=$ jika indikator horizontal lebih penting daripada indikator vertikal.

Tabel 1. Format tabel dalam pemberian bobot

\begin{tabular}{|c|c|c|c|c|c|c|}
\hline Faktor Internal/Eksternal & A & B & C & $\ldots$ & Total & Bobot \\
\hline A & & & & & & \\
\hline B & & & & & & \\
\hline C & & & & & & \\
\hline$\ldots$ & & & & & & \\
\hline \multicolumn{3}{|c|}{ Total keseluruhan variabel } & & 1,000 \\
\hline
\end{tabular}

Berikut ini rangkuman pemberian bobot dalam Sanggar Srengenge Mas. Dalam sanggar ini key person ada 3 orang yaitu Akhir Lusono, Marfuana, dan Sugiyanto.

Tabel 2. Pemberian Bobot Faktor Internal (Kekuatan \& Kelemahan)

Sanggar Srengenge Mas

\begin{tabular}{|c|c|c|c|c|}
\hline Faktor Internal & Akhir Lusono & Marfuana & Sugiyanto & Rata-rata \\
\hline A & 0,116 & 0,134 & 0,125 & 0,125 \\
\hline B & 0,143 & 0,143 & 0,098 & 0,128 \\
\hline C & 0,125 & 0,107 & 0,143 & 0,125 \\
\hline D & 0,152 & 0,125 & 0,116 & 0,122 \\
\hline
\end{tabular}




\begin{tabular}{|c|c|c|c|c|}
\hline $\mathrm{E}$ & 0,098 & 0,107 & 0,143 & $\mathbf{0 , 1 1 6}$ \\
\hline $\mathrm{F}$ & 0,080 & 0,152 & 0,134 & 0,122 \\
\hline $\mathrm{G}$ & 0,152 & 0,107 & 0,134 & $\mathbf{0 , 1 3 1}$ \\
\hline $\mathrm{H}$ & 0,134 & 0,125 & 0,107 & 0,122 \\
\hline \multicolumn{4}{|r|r|}{ Total Rata-rata } & 1,000 \\
\hline
\end{tabular}

Keterangan Indikator:

\begin{tabular}{|l|l|l|}
\hline A & $=$ & $\begin{array}{l}\text { Punya bidang garapan yang belum banyak disentuh oleh sanggar-sangar } \\
\text { lainnya. }\end{array}$ \\
\hline B & $=$ & $\begin{array}{l}\text { Punya anggota yang cukup militan dan fanatik terhadap program yang } \\
\text { dijalankan sanggar. }\end{array}$ \\
\hline C & $=$ & Punya jaringan media yang cukup luas. \\
\hline D & $=$ & Punya jadwal tampil yang tetap di sejumlah stasiun radio. \\
\hline E & $=$ & Punya peminat yang relatif terbatas. \\
\hline F & $=$ & Jumlah anggota yang tidak begitu banyak. \\
\hline G & $=$ & Jangkauan terbatas. \\
\hline H & $=$ & $\begin{array}{l}\text { Belum cukup menasional, karena programnya hanya menjangkau wilayah } \\
\text { DIY dan sebagian Jawa Tengah. }\end{array}$ \\
\hline
\end{tabular}

Pada Tabel 2 menunjukkan, bahwa faktor internal Sanggar Srengenge Mas (dilihat dari rata-rata) yang memiliki bobot tertinggi adalah " $G=$ Jangkauan terbatas" dan bobot yang terendah adalah " $E=$ Punya peminat yang relatif terbatas".

Tabel 3. Pemberian Bobot Faktor Eksternal (Peluang \& Ancaman)

Sanggar Srengenge Mas

\begin{tabular}{|c|c|c|c|c|}
\hline Faktor Eksternal & Akhir Lusono & Marfuana & Sugiyanto & Rata-rata \\
\hline A & 0,225 & 0,225 & 0,2 & $\mathbf{0 , 2 1 7}$ \\
\hline B & 0,2 & 0,2 & 0,15 & 0,183 \\
\hline C & 0,175 & 0,15 & 0,2 & $\mathbf{0 , 1 7 5}$ \\
\hline D & 0,175 & 0,225 & 0,225 & 0,208 \\
\hline E & 0,225 & 0,2 & 0,225 & $\mathbf{0 , 2 1 7}$ \\
\hline \multicolumn{5}{|r}{} \\
\hline
\end{tabular}

Keterangan:

\begin{tabular}{|l|c|l|}
\hline A & $=$ & $\begin{array}{l}\text { Kesempatan untuk berkembang masih terbuka dengan bersinergi dengan } \\
\text { pihak-pihak terkait. }\end{array}$ \\
\hline B & $=$ & Punya kesempatan untuk mendapatkan subsidi dana dari pemerintah. \\
\hline C & $=$ & Masih punya peluang untuk memperluas wilayah cakupan. \\
\hline D & $=$ & $\begin{array}{l}\text { Berkembangnya teknologi hiburan yang menawarkan banyak alternatif } \\
\text { hiburan. }\end{array}$ \\
\hline
\end{tabular}




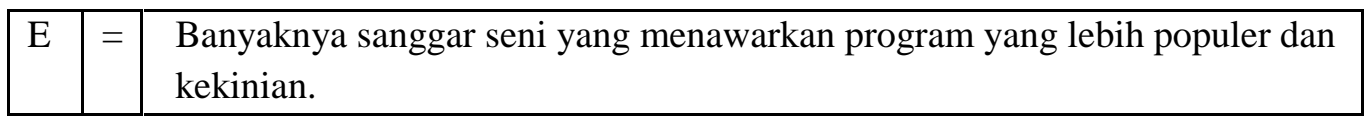

Pada Tabel 3 menunjukkan, bahwa faktor eksternal Sanggar Srengenge Mas (dilihat dari rata-rata) yang memiliki bobot tertinggi adalah " $A=$ Kesempatan untuk berkembang masih terbuka dengan bersinergi dengan pihak-pihak terkait" dan " $E=$ Banyaknya sanggar seni yang menawarkan program yang lebih popular dan kekinian”; dan bobot yang terendah adalah " $C=$ Masih punya peluang untuk memperluas wilayah cakupan”.

\section{Pemberian Peringkat}

Peringkat menggambarkan seberapa efektif strategi organisasi atau perusahaan saat ini dalam merespons faktor strategis yang ada. Penilaian peringkat untuk lingkungan diberikan dalam skala dengan pembagian sebagai berikut:

\begin{tabular}{|l|l|}
\hline \multicolumn{2}{|l|}{ a. Lingkungan Eksternal } \\
\hline $\begin{array}{l}\text { Aspek Peluang: } \\
\text { rating } 4=\text { respon sangat superior, } \\
\text { rating } 3=\text { respon di atas rata-rata, } \\
\text { rating } 2 \text { = respon rata-rata, dan } \\
\text { rating } 1=\text { respon di bawah rata-rata. } \\
\text { rating } 4=\text { respon di bawah rata-rata, } \\
\text { rating } 3=\text { respon rata-rata, } \\
\text { rating } 2=\text { respon di atas rata-rata, dan } \\
\text { rating } 1=\text { respon sangat superior. }\end{array}$ \\
\hline $\begin{array}{l}\text { b. Lingkungan Internal: } \\
\text { rating } 4=\text { sangat kuat, } \\
\text { rating } 3=\text { kuat, } \\
\text { rating } 2=\text { lemah, dan } \\
\text { rating } 1=\text { sangat lemah. }\end{array} \quad \begin{array}{l}\text { Aspek Kelemahan: } \\
\text { rating } 4=\text { sangat lemah, } \\
\text { rating } 3=\text { lemah, } \\
\text { rating } 2=\text { kuat, dan } \\
\text { rating } 1=\text { sangat kuat. }\end{array}$ \\
\hline
\end{tabular}

Berikut ini pemberian peringkat dalam Sanggar Srengenge Mas. Dalam usaha ini key person ada 3 orang yaitu Akhir Lusono, Marfuana, dan Sugiyanto.

a. Kekuatan

Tabel 4. Pemberian Peringkat Faktor Kekuatan Sanggar Srengenge Mas

\begin{tabular}{|c|c|c|c|c|c|}
\hline No & \multicolumn{1}{|c|}{ Kekuatan } & Akhir Lusono & Marfuana & Sugiyanto & Rata-rata \\
\hline A & $\begin{array}{l}\text { Punya bidang garapan yang } \\
\text { belum banyak disentuh oleh } \\
\text { sanggar-sangar lainnya. }\end{array}$ & 3 & 4 & 4 & $\mathbf{3 , 6 6 7}$ \\
\hline B & $\begin{array}{l}\text { Punya anggota yang cukup } \\
\text { militan dan fanatik terhadap } \\
\text { program yang dijalankan } \\
\text { sanggar }\end{array}$ & 4 & 3 & 3 & 3,333 \\
\hline C & $\begin{array}{l}\text { Punya jaringan media yang } \\
\text { cukup luas. }\end{array}$ & 3 & 3 & 3 & 3,000 \\
\hline
\end{tabular}




\begin{tabular}{|c|l|c|c|c|c|}
\hline D & $\begin{array}{l}\text { Punya jadwal tampil yang } \\
\text { tetap di sejumlah stasiun } \\
\text { radio. }\end{array}$ & 3 & 3 & 2 & $\mathbf{2 , 6 6 7}$ \\
\hline
\end{tabular}

Berdasarkan Tabel 4, peringkat terhadap kekuatan Sanggar Srengenge Mas yang terendah "Punya jadwal tampil yang tetap di sejumlah stasiun radio". Sedangkan peringkat yang tertinggi "Sanggar ini punya bidang garapan yang belum banyak disentuh oleh sanggar-sangar lainnya”.

b. Kelemahan

Tabel 5. Pemberian Peringkat Faktor Kelemahan Sanggar Srengenge Mas

\begin{tabular}{|c|l|c|c|c|c|}
\hline No & \multicolumn{1}{|c|}{ Kelemahan } & Akhir Lusono & Marfuana & Sugiyanto & Rata-rata \\
\hline E & $\begin{array}{l}\text { Punya peminat yang relatif } \\
\text { terbatas. }\end{array}$ & 3 & 3 & 2 & $\mathbf{2 , 6 6 7}$ \\
\hline F & $\begin{array}{l}\text { Jumlah anggota yang tidak } \\
\text { begitu banyak. }\end{array}$ & 2 & 4 & 2 & $\mathbf{2 , 6 6 7}$ \\
\hline G & Jangkauan terbatas. & 2 & 2 & 3 & 2,333 \\
\hline H & $\begin{array}{l}\text { Belum cukup menasional, } \\
\text { karena programnya hanya } \\
\text { menjangkau wilayah DIY } \\
\text { dan sebagian Jawa Tengah. }\end{array}$ & 1 & 1 & 3 & $\mathbf{1 , 6 6 7}$ \\
\hline
\end{tabular}

Berdasarkan Tabel 5, peringkat terhadap kelemahan Sanggar Srengenge Mas yang terendah "Belum cukup menasional, karena programnya hanya menjangkau wilayah DIY dan sebagian Jawa Tengah”. Sedangkan peringkat yang tertinggi terdapat dua nilai, yakni "Punya peminat yang relatif terbatas" dan "Jumlah anggota yang tidak begitu banyak."

c. Peluang

Tabel 6. Pemberian Peringkat Faktor Peluang Sanggar Srengenge Mas

\begin{tabular}{|c|l|c|c|c|c|}
\hline No & \multicolumn{1}{|c|}{ Peluang } & Akhir Lusono & Marfuana & Sugiyanto & Rata-rata \\
\hline A & $\begin{array}{l}\text { Kesempatan untuk } \\
\text { berkembang masih terbuka } \\
\text { dengan bersinergi dengan } \\
\text { pihak-pihak terkait. }\end{array}$ & 3 & 4 & 4 & $\mathbf{3 , 6 6 7}$ \\
\hline B & $\begin{array}{l}\text { Punya kesempatan untuk } \\
\text { mendapatkan subsidi dana } \\
\text { dari pemerintah. }\end{array}$ & 3 & 3 & 3 & 3.000 \\
\hline C & $\begin{array}{l}\text { Masih punya peluang untuk } \\
\text { memperluas wilayah } \\
\text { cakupan. }\end{array}$ & 3 & 2 & 3 & $\mathbf{2 , 6 6 7}$ \\
\hline
\end{tabular}

Berdasarkan Tabel 6, peringkat terhadap peluang Sanggar Srengenge Mas yang terendah adalah "Masih punya peluang untuk memperluas wilayah cakupan”. Sedangkan 
peringkat yang tertinggi adalah "Kesempatan untuk berkembang masih terbuka dengan bersinergi dengan pihak-pihak terkait”.

d. Ancaman

Tabel 7. Pemberian Peringkat Faktor Ancaman Sanggar Srengenge Mas

\begin{tabular}{|c|l|c|c|c|c|}
\hline No & \multicolumn{1}{|c|}{ Ancaman } & Akhir Lusono & Marfuana & Sugiyanto & Rata-rata \\
\hline E & $\begin{array}{l}\text { Berkembangnya teknologi } \\
\text { hiburan yang menawarkan } \\
\text { banyak alternatif hiburan. }\end{array}$ & 1 & 4 & 2 & $\mathbf{2 , 3 3 3}$ \\
\hline F & $\begin{array}{l}\text { Banyaknya sanggar seni } \\
\text { yang menawarkan } \\
\text { program yang lebih } \\
\text { populer dan kekinian. }\end{array}$ & 2 & 2 & 2 & $\mathbf{2 , 0 0 0}$ \\
\hline
\end{tabular}

Berdasarkan Tabel 7, peringkat terhadap ancaman Sanggar Srengenge Mas yang terendah adalah "Banyaknya sanggar seni yang menawarkan program yang lebih populer dan kekinian". Sedangkan peringkat yang tertinggi adalah "Berkembangnya teknologi hiburan yang menawarkan banyak alternatif hiburan".

\section{Hasil Matrik Internal Factor Evaluation (IFE)}

Tabel 8. Hasil Analisis Matrik IFE Sanggar Srengenge Mas

\begin{tabular}{|c|c|c|c|c|}
\hline No & Faktor Internal & Bobot & Peringkat & Nilai \\
\hline \multicolumn{5}{|c|}{ Kekuatan } \\
\hline A & $\begin{array}{l}\text { Punya bidang garapan yang belum banyak disentuh } \\
\text { oleh sanggar-sangar lainnya. }\end{array}$ & 0,125 & 3,667 & $\mathbf{0 , 4 5 8}$ \\
\hline $\mathrm{B}$ & $\begin{array}{l}\text { Punya anggota yang cukup militan dan fanatik } \\
\text { terhadap program yang dijalankan sanggar. }\end{array}$ & 0,128 & 3,333 & 0,427 \\
\hline $\mathrm{C}$ & Punya jaringan media yang cukup luas. & 0,125 & 3,000 & 0,375 \\
\hline $\mathrm{D}$ & $\begin{array}{l}\text { Punya jadwal tampil yang tetap di sejumlah stasiun } \\
\text { radio. }\end{array}$ & 0,122 & 2,667 & 0,425 \\
\hline \multicolumn{4}{|c|}{ Total Nilai Kekuatan } & $\mathbf{1 , 6 8 5}$ \\
\hline \multicolumn{5}{|c|}{ Kelemahan } \\
\hline $\mathrm{E}$ & Punya peminat yang relatif terbatas. & 0,116 & 2,667 & 0,442 \\
\hline $\mathrm{F}$ & Jumlah anggota yang tidak begitu banyak. & 0,122 & 2,667 & 0,299 \\
\hline $\mathrm{G}$ & Jangkauan terbatas. & 0,131 & 2,333 & 0,306 \\
\hline $\mathrm{H}$ & $\begin{array}{l}\text { Belum cukup menasional, karena programnya hanya } \\
\text { menjangkau wilayah DIY dan sebagian Jawa Tengah. }\end{array}$ & 0,122 & 1,667 & $\mathbf{0 , 2 0 3}$ \\
\hline \multicolumn{4}{|c|}{ Total Nilai Kelemahan } & 1,250 \\
\hline & Total Kekuatan dan Kelemahan & 1,000 & - & 2,935 \\
\hline
\end{tabular}

Pada Tabel 8, hasil analisis matrik IFE yaitu nilai tertinggi adalah "Punya bidang garapan yang belum banyak disentuh oleh sanggar-sangar lainnya” yaitu sebesar $\mathbf{0 , 4 5 8 ,}$ 
sedangkan yang terendah adalah "Belum cukup menasional, karena programnya hanyak menjangkau wilayah DIY dan sebagian Jawa Tengah" sebesar 0,203.

\section{Hasil Matriks External Factor Evaluation (EFE)}

Tabel 9. Hasil Analisis Matriks EFE Sanggar Srengenge Mas

\begin{tabular}{|c|l|c|c|c|}
\hline No & \multicolumn{1}{|c|}{ Faktor Eksternal } & Bobot & Peringkat & Nilai \\
\hline Peluang & $\begin{array}{l}\text { Kesempatan untuk berkembang masih terbuka } \\
\text { dengan bersinergi dengan pihak-pihak terkait. }\end{array}$ & 0,217 & 3,667 & $\mathbf{0 , 7 9 6}$ \\
\hline B & $\begin{array}{l}\text { Punya kesempatan untuk mendapatkan subsidi dana } \\
\text { dari pemerintah. }\end{array}$ & 0,183 & 3.000 & 0,540 \\
\hline C & $\begin{array}{l}\text { Masih punya peluang untuk memperluas wilayah } \\
\text { cakupan. }\end{array}$ & 0,175 & 2,667 & 0,467 \\
\hline \multicolumn{3}{|c|}{ Total Nilai Peluang } & $\mathbf{1 , 8 0 3}$ \\
\hline Ancaman & 0,208 & 2,333 & 0,485 \\
\hline E & $\begin{array}{l}\text { Berkembangnya teknologi hiburan yang } \\
\text { menawarkan banyak alternatif hiburan. }\end{array}$ & $\mathbf{0 , 4 3 4}$ \\
\hline F & $\begin{array}{l}\text { Banyaknya sanggar seni yang menawarkan } \\
\text { program yang lebih populer dan kekinian. }\end{array}$ & 0,217 & 2,000 \\
\hline \multicolumn{3}{|c|}{ Total peluang dan ancaman } & $\mathbf{1 , 0 0 0}$ & - \\
\hline \multicolumn{3}{|c|}{} \\
\hline
\end{tabular}

Pada Tabel 9, hasil analisis matrik EFE yaitu nilai tertinggi "Kesempatan untuk berkembang masih terbuka dengan bersinergi dengan pihak-pihak terkait” sebesar 0,796, sedangkan yang terendah adalah "Banyaknya sanggar seni yang menawarkan program yang lebih populer dan kekinian” sebesar $\mathbf{0 , 4 3 4}$.

3. Tahap Pencocokan

a. Analisis Matriks IE (Internal-Eksternal)

Tahap ini merupakan tahap pencocokan dengan memasukkan hasil pembobotan dan peringkat pada matriks EFE dan IFE ke dalam matriks IE. Total nilai tertimbang pada matriks EFE dan IFE akan berada pada kisaran 1,0 (terendah) hingga 4,0 (tertinggi), dengan nilai rata-rata 2,5. Matriks IE mempunyai sembilan sel strategi yang dapat dikelompokkan menjadi tiga sel strategi utama, yaitu:

a. Growth and Build (Tumbuh dan Bina) berada dalam sel I, II, dan IV. Strategi yang cocok adalah intensif (penetrasi pasar, pengembangan pasar, dan pengembangan produk) atau integrasi (integrasi ke belakang, integrasi ke depan, dan integrasi horizontal).

b. Hold and Maintain (Pertahankan dan Pelihara) dilakukan untuk sel III, V, dan VII. Strategi umum yang dipakai adalah penetrasi pasar dan pengembangan produk.

c. Harvest or Divest (Panen atau Divestasi) dipakai untuk sel VI, VIII, dan IX. Strategi umum yang dipakai adalah strategi divestasi, strategi diversifikasi konglomerat, dan strategi likuidasi. Matriks IE dapat dilihat pada tabel berikut. 
Tabel 10. Matrik IE SWOT

\begin{tabular}{|c|c|c|c|c|}
\hline \multirow{5}{*}{ 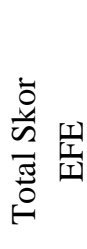 } & \multicolumn{4}{|c|}{ Total Skor IFE } \\
\hline & 4.0 & \multicolumn{2}{|c|}{3.0} & 1.0 \\
\hline & 3.0 & I & II & III \\
\hline & 2.0 & IV & $\mathrm{V}$ & VI \\
\hline & 1.0 & VII & VIII & IX \\
\hline
\end{tabular}

Dari hasil perhitungan di atas, diperoleh hasil IFE sebesar 2,935 dan EFE sebesar 2,722. Angka tersebut selanjutnya dapat menggambarkan posisi Sanggar Srengenge Mas melalui Matriks IE.

Tabel 11. Matrik IE Sanggar Srengenge Mas

\begin{tabular}{|c|c|c|c|c|}
\hline \multirow{5}{*}{ 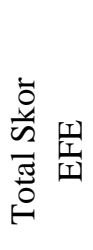 } & \multicolumn{4}{|c|}{ Total Skor IFE } \\
\hline & 4.0 & \multicolumn{2}{|c|}{3.0} & 1.0 \\
\hline & 3.0 & I & II & III \\
\hline & 2.0 & IV & V & VI \\
\hline & 1.0 & VII & VIII & IX \\
\hline
\end{tabular}
Maintain (Pertahankan dan Pelihara) karena berada pada posisi V. Strategi umum yang dipakai adalah penetrasi pasar dan pengembangan produk.

Kuadran Analisis SWOT

Untuk kuadran analisis SWOT Sanggar Srengenge Mas dihitung berdasarkan berikut:

Nilai Faktor Internal $=$ Kekuatan - Kelemahan

$$
\begin{aligned}
& =1,685-1,250 \\
& =0,435
\end{aligned}
$$

Nilai Faktor Eksternal $=$ Peluang - Ancaman

$$
\begin{aligned}
& =1,803-0,919 \\
& =\mathbf{0 , 8 8 4}
\end{aligned}
$$

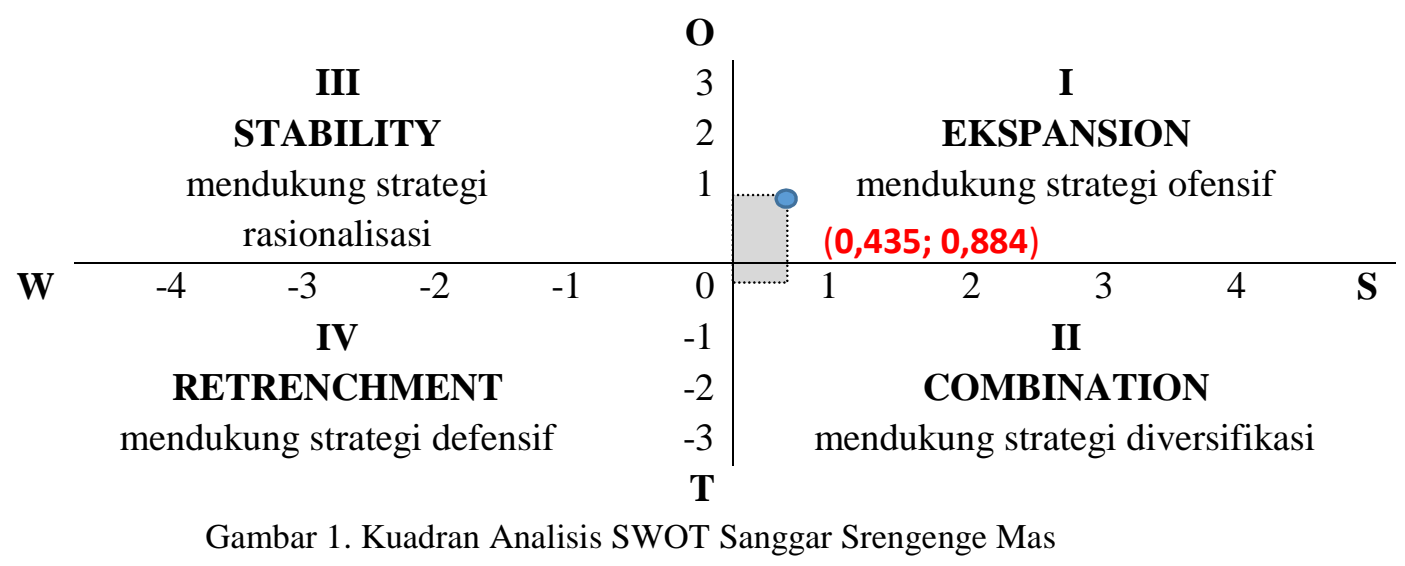


Kuadran Analisis SWOT Sanggar Srengenge Mas menunjukkan posisinya berada pada kuadran I sehingga diperlukan pemilihan strategi yang berupa penggunaan setiap kekuatan untuk menghadapi setiap ancaman dengan mendukung strategi ofensif untuk menciptakan peluang. Selanjutnya adalah perumusan strategi-strategi melalui matriks SWOT yang diperoleh dengan memasangkan faktor-faktor eksternal dengan faktor-faktor internal. Dalam matriks SWOT diperlihatkan kesesuaian antara kekuatan, kelemahan, peluang, dan ancaman.

\section{Matriks SWOT}

Matriks SWOT diperoleh dengan memasangkan faktor-faktor eksternal dengan faktor-faktor internal. Dalam matriks SWOT diperlihatkan kesesuaian antara kekuatan, kelemahan, peluang, dan ancaman seperti terlihat pada tabel berikut.

Tabel 12. Alternatif Strategi dalam Matriks SWOT

\begin{tabular}{|l|l|l|}
\hline \multicolumn{1}{|c|}{ Internal } & \multicolumn{1}{c|}{$\begin{array}{c}\text { Strength }(S) \\
\text { *Faktor Kekuatan }\end{array}$} & \multicolumn{1}{c|}{$\begin{array}{c}\text { Weakness }(W) \\
\text { *Faktor Kelemahan }\end{array}$} \\
\hline $\begin{array}{l}\text { Opportunities }(O) \\
\text { *Faktor Peluang }\end{array}$ & $\begin{array}{l}\text { Strategi SO } \\
\text { Ciptakan strategi yang } \\
\text { menggunakan kekuatan untuk } \\
\text { memanfaatkan peluang. }\end{array}$ & $\begin{array}{l}\text { Strategi WO } \\
\text { Ciptakan strategi yang } \\
\text { meminimalkan kelemahan } \\
\text { untuk memanfaatkan peluang. }\end{array}$ \\
\hline $\begin{array}{l}\text { Threaths }(T) \\
\text { *Faktor Ancaman }\end{array}$ & $\begin{array}{l}\text { Strategi ST } \\
\text { Ciptakan strategi yang } \\
\text { menggunakan kekuatan untuk } \\
\text { mengatasi ancaman. }\end{array}$ & $\begin{array}{l}\text { Strategi TW } \\
\text { Ciptakan strategi yang } \\
\text { meminimalkan kelemahan dan } \\
\text { menghindari ancaman. }\end{array}$ \\
\hline
\end{tabular}

4. Tahapan Keputusan

Hasil Matriks SWOT memberikan beberapa alternatif strategi, yaitu:

\begin{tabular}{|l|c|l|l|}
\hline SO & $:$ & $\begin{array}{l}\text { 1. Mengembangkan bidang garapan yang belum banyak disentuh sanggar-sanggar } \\
\text { lainnya dengan mengoptimalkan peran anggota yang cukup militan dan fanatik } \\
\text { dengan bersinergi dengan pihak-pihak terkait. } \\
\text { 2. Memanfaatkan jaringan media yang cukup luas dan jadwal tampil yang tetap di } \\
\text { sejumlah stasiun radio untuk memperluas wilayah cakupan. }\end{array}$ \\
\hline WO & $:$ & $\begin{array}{l}\text { 1. Menjaring peminat yang lebih banyak sekaligus menambah anggota dengan } \\
\text { memperluas wilayah cakupan. } \\
\text { 2. Memperluas jangkauan agar lebih menasional untuk bisa mendapatkan subsidi } \\
\text { dana dari pemerintah. }\end{array}$ \\
\hline ST & $:$ & $\begin{array}{l}\text { 1. Mengembangkan bidang garapan yang belum banyak disentuh sanggar lainnya } \\
\text { untuk menarik minat lebih banyak orang untuk ikut terlibat. }\end{array}$ \\
\hline WT & $:$ & $\begin{array}{l}\text { 1. Menarik minat masyarakat dengan memanfaatkan perkembangan teknologi } \\
\text { di tengah berkembangnya teknologi hiburan. } \\
\text { hiburan sekaligus untuk bisa bersaing dengan sanggar-sanggar lainnya. } \\
\text { 2. Memperluas jangkauan dengan memanfaatkan perkembangan teknologi hiburan. }\end{array}$ \\
\hline
\end{tabular}


- Tahap keputusan berdasarkan matriks IE.

Posisi Sanggar Srengenge Mas Matriks IE menunjukkan Hold and Maintain (Pertahankan dan Pelihara) karena berada pada posisi V. Strategi umum yang dipakai adalah penetrasi pasar dan pengembangan produk.

- Penetrasi pasar: memasyarakatkan karya-karya Sanggar Srengenge Mas dengan gencar dengan memanfaatkan jaringan media.

- Pengembangan produk/karya: mengembangkan karya-karya Sangar Srengenge Mas dan terus melakukan inovasi.

- Tahap keputusan berdasarkan kuadran analisis SWOT.

Kuadran analisis SWOT Sanggar Srengenge Mas menunjukkan posisinya berada pada kuadran I Expansion sehingga diperlukan pemilihan strategi yang berupa penggunaan setiap Kekuatan untuk menghadapi setiap Ancaman.

Posisi tersebut mengarah pada strategi ST yaitu:

1. Menjaring anggota dan memperluas cakupan dengan menghasilkan karya-karya yang inovatif untuk menarik minat masyarakat untuk ikut terlibat.

2. Mempertahankan eksistensi dengan memperbanyak pementasan agar lebih dikenal secara luas di masyarakat.

\section{PEMBAHASAN}

\section{Strategi Generik dan Variasi Strategi yang Saat Ini Diterapkan oleh Sanggar Srengenge Mas}

Strategi generik yang diterapkan di Sanggar Srengenge Mas saat ini adalah Fokus. Strategi fokus itu digunakan untuk membangun keunggulan bersaing dalam suatu segmen pasar yang lebih sempit dan menghindari konfrontasi langsung dengan para pesaingnya. Pesaing di sini adalah sanggar-sanggar lain yang menawarkan jenis kesenian yang lebih populer dan kekinian, sesuai dengan tuntutan pasar hiburan.

Berdasar teorinya, strategi jenis itu ditujukan untuk melayani kebutuhan konsumen yang jumlahnya relatif kecil dan dalam pengambilan keputusannya untuk membeli relatif tidak dipengaruhi oleh harga. Dalam pelaksanaannya - terutama pada perusahaan skala menengah dan besar - strategi fokus diintegrasikan dengan salah satu dari dua strategi generik lainnya: strategi biaya rendah atau strategi pembedaan karakteristik produk. Strategi ini biasa digunakan oleh pemasok "niche market" (segmen khusus/khas dalam suatu pasar tertentu).

Strategi yang digunakan:

a) Overall cost leadership (fokus ke pesaing daripada ke pelanggan, biaya murah/bisa dilakukan karena mengusahakan biaya produksi murah).

b) Differentiation (melayani pangsa pasar yang kecil sehingga lebih baik dari para pesaing).

Penerapan strategi generik di atas, apabila dihubungkan dengan strategi yang terdapat di Sanggar Srengenge Mas terlihat dari kebijakan pengelola sanggar yang memilih segmen pada komunitas tertentu, yang sebelumnya memang sudah punya ketertarikan terhadap seni tradisi, khususnya seni gurit, tari tradisional, dan penulisan cerita pendek berbahasa Jawa, serta pementasan drama berbahasa Jawa. 
Sedangkan variasi strategi yang diterapkan oleh Sanggar Srengenge Mas adalah Pengembangan Karya di antaranya dengan memperbanyak variasai penyajian yang lebih menarik dan Diversifikasi Konsentrik (melakukan inovasi karya).

Strategi generik \& variasi strategi apa yang semestinya dijalankan Sanggar Srengenge Mas untuk saat ini, berdasarkan hasil analisis Matrik IE dan Kuadran SWOT, yaitu Expansion mendukung strategi ofensif. Dilihat dari hasil analisis matrik IE, posisi Sanggar Srengenge Mas menunjukkan Hold and Maintain (Pertahankan dan Pelihara) karena berada pada posisi V. Strategi umum yang dipakai adalah penetrasi pasar dan pengembangan produk.

Sedangkan menurut hasil kuadran SWOT posisi usahanya berada pada kuadran I yaitu Strategi Generik Expansion. Oleh karena itu, dalam usaha ini strategi generik yang akan digunakan adalah Expansion. Untuk variasi strategi yang akan digunakan adalah ofensif (variasi strategi kuadran SWOT) serta penetrasi pasar dan pengembangan produk (variasi strategi dari matrik IE).

Variasi strategi ofensif dilakukan dengan cara perluasan jangkauan dan jaringan yang mendukung upaya pelestarian jenis-jenis seni tradisi yang menjadi consent Sanggar Srengenge Mas, sehingga produk-produk seni tradisi yang dikembangakan Srengenge Mas tidak hanya menyasar pada kalangan tertentu saja yang jumlahnya relatif terbatas.

Untuk memperluas jangkauan dapat dilakukan dengan menggunakan srategi penetrasi pasar, yakni dengan melakukan upaya sosialisasi yang lebih gencar dan mencakup pasar yang lebih luas.

Untuk dapat menjangkau pasar yang lebih luas, perlu dilakukan pengembangan produk/karya sehingga lebih menarik bagi kalangan yang lebih luas. Pengembangan karya di sini bisa lebih fleksibel dengan lebih membuka diri terhadap masuknya seni tradisi yang lebih populer untuk dikombinasikan dengan seni tradisi, tanpa menghilangkan nilai-nilai yang ada di dalamnya.

\section{KESIMPULAN}

Tujuan utama pada penyusunan jurnal ini adalah untuk mengembangkan strategi Sanggar Srengenge Mas. Berdasarkan analisis Matrik IE (Internal-Eksternal) dan Kuadran SWOT maka dapat disimpulkan strategi Sanggar Srengenge Mas sebagai berikut.

\begin{tabular}{|l|l|}
\hline Strategi Generik & Ekspansi \\
\hline Variasi Strategi & $\begin{array}{l}\text { 1. Penetrasi Pasar: Memasyarakatkan seni trradisi yang } \\
\text { menjadi consent Sangggar Srengenge Mas dengan gencar } \\
\text { dengan memanfaatkan jaringan media yang ada. }\end{array}$ \\
& $\begin{array}{l}\text { 2. Pengembangan Pasar: Memperluas jangkauan dengan } \\
\text { memanfaatkan jaringan yang ada. }\end{array}$ \\
& $\begin{array}{l}\text { 3. Pengembangan Produk: Mengembangkan karya dengan } \\
\text { terus berinovasi untuk menambah daya tarik karya dan } \\
\text { mudah diterima oleh khalayak. }\end{array}$ \\
\hline
\end{tabular}


Saran

Sanggar Srengenge Mas mempunyai bidang garapan yang terbatas dan kurang populer, seperti: seni gurit, tari tradisional, dan penulisan cerita pendek berbahasa Jawa, serta pementasan drama berbahasa Jawa. Untuk itu dibutuhkan strategi yang tepat untuk dapat hidup dan berkembang.

Berdasarkan hasil analisis Matrik IE dan Kuadran SWOT, telah memunculkan rekomendasi strategi-strategi yang bisa digunakan untuk mendukung pencapaian visi dan misi sanggar. Namun dalam penerapan strategi ini hendaknya disesuaikan pula dengan perkembangan industri hiburan yang tidak bisa diabaikan dalam upaya pelestarian seni tradisi.

\section{KEPUSTAKAAN}

David Fred R. 2010. Manajemen Strategis. Jakarta: Salemba Empat.

Fajar Nuraini, Dwi Fatimah. 2017. Teknik Analisis SWOT. Jakarta: Anak Hebat Indonesia. Rangkuti, Freddry. 2016. Analisis SWOT: Teknis Membedah Kasus Bisnis Cara Perhitungan Bobot, Ratting dan OCAL. Jakarta: PT Gramedia Pustaka Utama. 